\title{
The Fusion and Embodiment Analysis of Chinese Traditional Culture Elements in Environmental Art Design
}

\author{
Xiangkai Wu \\ College of Art and Design, Nanyang Institute of Technology, China
}

Keywords: Environmental art, art design, traditional culture, fusion, embodiment.

\begin{abstract}
Chinese traditional culture has five thousand in the history of country's collective wisdom crystallization; it is the human common spiritual wealth. In today's society of political, economic and cultural exchanges between the increasingly frequent, Chinese traditional culture also attaches great importance to the people at home and abroad, and the comprehensive, application and development in many areas, effectively guide the development of the modern environmental art design. In this paper, on the basis of the reality of China's traditional culture and environmental art design briefly elaborated the related theory, analyses the traditional culture elements in the application of environmental art and promote the role, from positive and negative two aspects of Chinese traditional culture into the environment art design is discussed. On this basis, the trend of future development of environmental art design is discussed.
\end{abstract}

\section{Introduction}

Today's China, quickening the pace of life, the people of China and foreign exchange frequently, leading to the design style of western countries in the field of design in our country there are many aspects of influence, in the environmental art design also has become a popular trend, but as a culture of our traditional Chinese elements should be inherit and carry forward, make culture do not break refined charm of the Times [1]. In many of the environmental art design at home and abroad, the application of Chinese element has an important place.

Chinese traditional elements are such a high social status, this is inseparable from the creator of the traditional culture of the cognition of life, and the stubborn creative ability, made the textual research of history, the traditional things undergo lingering and integrated into the modern environmental art design field.

\section{Traditional Chinese elements}

Who in the fusion of the Chinese nation, gradually formed in the process of evolution and development, created by the Chinese, inheritance, reflects the Chinese humanistic spirit and folk psychology, has the qualities of Chinese cultural achievements, is the traditional Chinese elements, including tangible material symbols (calligraphy, painting, seal carving, Chinese knot, face book, paper-cut, text, COINS, ancient weapon, painted pottery, grain appearance, dress) and the spirit of the invisible content, namely material culture elements and spiritual culture elements. Such as ideology, morality, like value system, customs, habits and customs, religion, architecture, art, science and technology, legal, ethical, and so on, up to three sovereigns, down to the Song, Yuan, Ming and Qing dynasties, the Great Wall to the Palace Museum, small to nail the lattice [1]. Chinese traditional culture is the Chinese traditional elements, but not all Chinese elements are equal to the Chinese traditional culture, including modern Chinese culture. 


\section{The present situation of the environmental art design}

Environmental art design is an emerging, interdisciplinary comprehensive professional, involving art, sculpture, decoration, building, garden art, human body engineering, and school of design, material science, psychology, and other fields.

\subsection{Design patterns about the western powerful culture design in China.}

Many Chinese designers and modern scholars believe that the traditional Fengshui is superstitious, lifetime, causing the theories in this field is blank, makes the introduction of western modern design concept [2]. Standing in the perspective of culture, we ancient civilizations in the contemporary but few belong to their own breeding out of local civilization construction environment concept and the form. With the blind worship of the west, now in China the birth of "hybrid" everywhere, in a "Chinese food tasteless, foreigners see ridiculous" awkward situation. Many have distinguishing feature each, cultural relics, ancient town gradually fade in the history of the wind and rain, lost the original characteristics, and gradually be relentless construction in the hands of them from our memory erased. Urban construction machine-made, lost the original local characteristics and cultural characteristics.

\subsection{The traditional design thinking by the isolation of modern civilization.}

In China, many in the true sense to save the case of Chinese traditional architectural environment design thinking and practice, are mostly concentrated in the remote countryside, also maintained a more local regional culture characteristics [2]. The ancient residential architecture and the external environment, it is representative of Chinese traditional architectural environment design thinking and practice. But with the development of media communication and the invasion of the western design ideas, the Chinese vernacular architecture with that kind of space structure of self-sufficiency, and the "nature and humanity" of the nature of the harmonious coexistence of people and for the environment is becoming lost.

\section{The connotation of Chinese traditional culture and modern environment design}

\subsection{The basic connotation of Chinese traditional culture.}

Traditional culture is to point to in a long historical period in the history of a nation's inheritance and all sorts of spiritual culture and moral concept of organic combination, but also the important of a national cohesion and creativity [3]. Our country is a five thousand - year - old civilization, formed in the course of several thousand years history of deep cultural inside information, is refers to the use of Chinese traditional culture elements in architecture, and literature, painting, some of the intention, clothes, etc. Represented by Confucian culture of the Chinese traditional culture in the cultural construction of the modern economy still has a fresh vitality, traditional culture is the Chinese nation to the survival and development.

\subsection{The connotation of modern environment art design.}

Modern environmental art design through the environment design or architectural design embodies the basic cultural connotation and creation intention of the designer [3]. The fusion of work stress and environmental relationship, emphasize the artistic expression of the author, and mainly through the work of material texture, color, luster, external shape and size proportion to express, including indoor decoration, landscape gardening, external morphology, roads, decoration and so on all belongs to the category of environmental art design.

\section{Chinese traditional culture and the relationship between the environmental art design}

Environmental art design is an emerging, interdisciplinary comprehensive professional, involving art, sculpture, decoration, building, garden art, human body engineering, and school of design, material science, psychology, and other fields. 


\subsection{Traditional culture elements add new vitality to the environmental design.}

Modern environmental designers consciously set up into the traditional national culture creation concept, effective in environmental art design into the traditional culture symbol, the use of modern means of artistic creation to bring new vitality and creativity, traditional culture and perfect embodiment of the people in the region and national cultural characteristics, and to provide for local people to live, the spatial modeling of appreciation, art exchange, form a pattern of art creation with Chinese characteristics, to promote China's traditional culture and the rapid development of modern art design [4].

\subsection{The traditional culture to enhance of implicitness of environmental art design.}

In the Chinese tradition has exquisite implicative, deep, this also directly mapped to the contemporary environmental design field [5]. Influenced by traditional culture concept, environment of Chinese contemporary art works mostly focus on the expression of rational thinking and emotional art, artistic expression and deep, through a variety of implicative art form to portray the association and imagination of space, produce plenty of artistic appeal, raise the entire democratic artistic creativity, which is the artistic charm of the Chinese culture.

\section{Fusion and embodiment of traditional culture elements in the environmental art design}

In this day and age, along with the advancement of globalization, the height of social modernization and rapid information, cultural landscape is also changed, the traditional Chinese culture and art has also been a new trend, new ideas, and the influence of globalization and localization of the two-way development become the basic direction of cultural development of the world today [4]. The traditional aesthetic idea and the design elements back into the mainstream of traditional culture, in what is now the environmental art design gradually began to play a huge role. The application of Chinese traditional culture elements in environment art design has the following several aspects:

\subsection{The application of traditional graphics.}

Direct application of traditional graphics in modern art design, the first thing to clarify a concept, it is not simple and piled up, mainly is the traditional culture elements to dependent on a new carrier, to reset a visual language environment, continue to play the original graphic information [5]. This direct use should be the concept of a new integration, is a kind of positive performance and creation, it needs to take into account the adapted to the environment, the specific process and carrier materials with a range of factors, such as adopting the combination of the most appropriate to increase the value of graphics, show the unique charm.

\subsection{The application of meaning form.}

In ancient Chinese architecture and interior decoration art, people used to use more implicative rendering technique to SMS, from the construction of the external form design to indoor and outdoor space layout, design and furnishings, choosing the appropriate culture to the specific environment carrying the rich cultural connotations [4]. Design of modern environment art said these methods for metaphor. Metaphor of modern environmental art design, namely, in a certain environment constitute elements and ways table into the environment outside the spirit of ontology, such as cultural connotation, meaning, value orientation and so on a higher level of cultural information, shown as below Fig. 1.

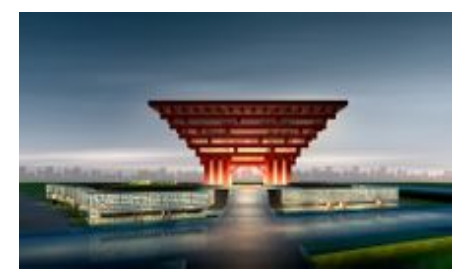

Fig. 1 The Shanghai world expo China pavilion 


\subsection{Shape and simultaneously.}

For traditional Chinese lines not only has length, width and direction more messiness, show that the speed and power, to promote dialogue and exchanges between the east and west cultures. Such as classical Chinese poetry in the application of modern environmental art design is the best performance and spirit "and" [5]. To translate poetry for specific environmental art design, environmental design art more poetic, this spirit of the idea to reality in three dimensional space design art is like dreams extremely attractive. Starting from the poems of poets incisive, it is vividly and deep understanding of landscape.

\subsection{The advantages of traditional culture in the modern environment art.}

Form of Chinese traditional culture is rich, for the environment art design, traditional decorative elements play an important role. A house and a base personality is distinct, stone, carved beams and painted exquisite colorful, to strengthen the traditional architecture of personality. Modern designers have made a lot of effort to make it with new material, new structure and new technology on the basis of combination of new buildings (see as Fig. 2). In the modern environment art design, the use of the traditional culture elements, take its shape not only, more with its meaning [4]. A traditional decorative element in China's profound traditional culture, to improve the development of our modern design provides a continuously material support. In to realize the advantage of the traditional decorative elements in modern design at the same time, we also must try to turn this advantage to design strength, to seek more and better ways and methods.

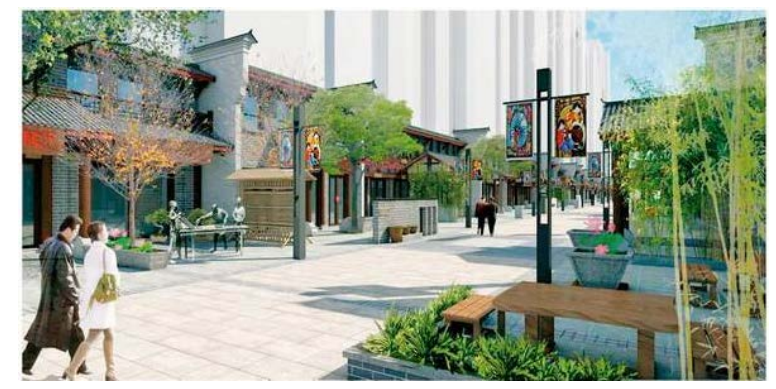

Fig. 2 Chinese elements applied in public environmental art design

\subsection{The embodiment of the traditional cultural elements in building.}

Traditional designs, patterns and shape can be as the prototype of the modern design form creation. Shanghai Jinmao building and the design of the Beijing capital museum is derived from the traditional decorative elements, and then in the pattern of traditional decorative elements and form for the design of the deep [5]. The capital museum building itself is a blend of classical beauty and modern beauty in the integration of architecture art, both with rich tradition of national characteristics, and present distinct contemporary feeling. In environment art design, the uses of plants to decorate also have exquisite. Such as the traditional garden multi-purpose "plum, orchid, bamboo, chrysanthemum" "plants, such as this is a metaphor, with some of the physical characteristics of plants, on people's minds, praise the spirit of the noble moral character.

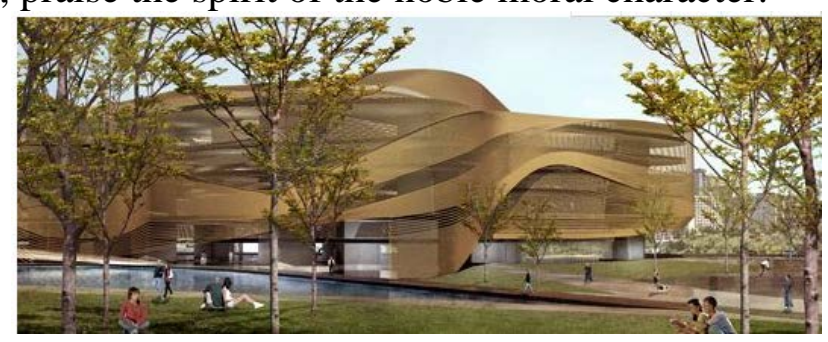

Fig. 3 Chinese elements applied in building art design

\subsection{Traditional culture elements in the embodiment of the design idea and design methods.}

As the design methods and ideas of the Chinese traditional garden, in the modern environment 
design art has been widely used [6]. Most widely used is the urban landscape design, the modern real estate industry has developed rapidly, competition is very intense, very cultural connotation of building more consumer favorite, so a lot of community planning and landscape design will be Chinese traditional garden design concept is blended in among them.

\subsection{The reflection of traditional culture elements in environment art theory.}

The study of traditional Chinese society and culture, by the traditional culture elements in a lot of visual are literature materials. Various forms of complex, design a variety of traditional culture elements will not only bring us a strong visual impact, can help us understand more form behind reflected in social politics, economy and culture. At the same time, according to the characteristic of traditional culture elements in different periods, can also study the social history, providing theoretical basis for the development of environmental art design [6].

With the spread of poetry to the beautiful scenery, such as people with vision and imagination for a particular landscape have put forward various views and comments, subsequent visitors to visit there, according to those who view and admire, it is a collective. There are poetry short and pithy, catchy, widely circulated. Has a huge role in the hint, inspire the thinking of visitors, can also be remembered that landscape.

\section{Conclusion}

In view of this, China's environmental art design development should go a suitable for our national conditions, both at the same time to follow the trend of The Times of design with Chinese culture characteristics. Creation is suitable for the work and show the Chinese nationality. Traditional elements to combine with modern environmental design is reasonable, should be the essence of traditional spirit of nature reflected in the design is not a hard copy of traditional style elements.

\section{References}

[1] Z.X. Huang, Environmental art design, Southwest normal university, 2009, vol. 2, pp. 2-4.

[2] G.H. Wu and Ch.L. Zhu, Environmental art design, Shanghai journal of painting and calligraphy, 2003, vol. 3, pp. 44-46.

[3] H.M. Zhou, The regional ecological construction and the ecological analysis of interior design, Interior design and decoration, 2011, vol. 7, pp. 32-35.

[4] J.T. He and Y.M. Pan, The design of the world expo China pavilion, China pavilion, 2010, vol. 6, pp. 21-24.

[5] X. Sh. Chen, Art and modern design, Hefei University of technology press, 2007, vol. 2, pp. 44-46.

[6] Y.Z. Li, Environmental art design, The Chinese people's university press, 2014, vol. 11, pp. 41-45. 